\title{
Paideusis
}

\section{Environmental Education, Student Autonomy and the Non-Idolization of Science}

\section{David P. Burns and Stephen P. Norris}

Volume 21, Number 1, 2013

Contemplative Practice, Education, and Socio-Political

Transformation (Part Two)

URI: https://id.erudit.org/iderudit/1071574ar

DOI: https://doi.org/10.7202/1071574ar

See table of contents

Publisher(s)

Canadian Philosophy of Education Society

ISSN

0838-4517 (print)

1916-0348 (digital)

Explore this journal

Cite this document

Burns, D. \& Norris, S. (2013). Environmental Education, Student Autonomy and the Non-Idolization of Science. Paideusis, 21(1), 49-50.

https://doi.org/10.7202/1071574ar viewed online.

https://apropos.erudit.org/en/users/policy-on-use/ 


\section{Environmental Education, Student Autonomy, and the Non-Idolization of Science}

\author{
DAVID P. BURNS \\ Educational Studies, \\ Kwantlen Polytechnic University
}

\author{
STEPHEN P. NORRIS \\ Educational Policy Studies, \\ University of Alberta
}

We are pleased to see that our work (Burns \& Norris, 2009) has attracted interest and a critical response in Paideusis (Niblett, 2012). We had hoped that paper would stimulate a discussion about the apparent assumptions being made in the environmental education literature in Canada, and it appears to have done just that.

We do have several reservations, however, about the content of the argument presented by Niblett. We will restrict this short rejoinder to our most serious concern with the paper. Niblett's argument fails to provide an accurate account of our position and hence holds little relevance for our position. Niblett asks "[us] to consider a reformulation of [our] position with a view to cautioning science educators about the challenges of taking on contentious issues in the classroom, but that does not absolutely condemn pedagogies that offer students curricular opportunities to engage with environmental advocacy" (p. 4).

Such "absolute condemnation" is not an argument that we make at any stage of our analysis or in any of our writing on this subject. Our actual position is that "science education should not be involved in furthering particular, contested assumptions and propositions" (p. 36), by which we mean that science education should not be an advocate for one position or another. We go on to provide several concrete examples of this thesis. We note, for example, that some scholars of science education seek to press students to develop certain attitudes about the environment, certain modes of appreciation for it, and certain relationships with it (p. 37). We object to pressing students into adopting one contested view in favour of others, but we do not argue that students should be denied opportunities to engage with various positions. Indeed, we explicitly argue for student autonomy and for supporting this autonomy by helping students to grasp that contestation that exists and to develop the tools of reasoning needed to make their own choices. It is difficult to understand how one might interpret our defense of student choice as repression of student opportunities for engagement, which is what Niblett's above request of us seems to imply. The implication is antithetical to our actual position.

At other points in the paper, Niblett appears to understand our stated position. He remarks that we "rightly note that science pedagogies should go beyond the delivery of objective findings and help students to engage with the meaning of these findings for societies" (p. 5). If it is the case that we believe that science education must go beyond objective findings to engage with social questions, then clearly we support engagement with activism. Activism is part of social and political life. We argue that the contentious goals of various activist positions should not as well be curricular goals. We do not argue, nor do we believe, that students should be prevented from engaging in critical discussion of activist positions as part of the science curriculum. There is an enormous difference between forbidding engagement with activism, and championing specific agendas of particular activist positions. We argue that science education needs to teach students how to engage without championing particular environmental causes.

Another misinterpretation of our position relates to the charge of scientism and close-mindedness advanced later in Niblett's rebuttal. He claims that "Burns and Norris (2009) call for open-minded environmental education within the science classroom without any discussion of the need to be open-minded about the value of scientific knowledge itself' (p. 6). Although we do not engage in extended discussion of the matter, we explicitly state that we 
"recognize that science embodies prescriptive norms, but these norms properly refer to the practice of science, and are themselves open to critique and revision" (emphasis added, p. 41). Given that we state so directly that the norms of science are open to revision, it is difficult to understand why our position might be associated with scientism, wherein "the legitimacy of science knowledge may be reified to the extent that commonly accepted parameters of science inquiry are placed on a pedestal beyond the reach of the critical questioning that is necessary for open-minded education" (Niblett, p. 6). Placing science on a pedestal is precisely opposite to our stated beliefs and interests.

We have attempted to show with the two examples above that the central threads of Niblett's critique mistakenly portray our position. We do not forbid engagement with social issues or activism. Quite the contrary, we encourage such engagement at the levels of understanding and critique. We do criticize the use of activism in place of open intellectual engagement in the science classroom to further particular environmental ends. We do not place scientific norms outside of critical questioning. Indeed, we define science via critical questioning. We sincerely welcome efforts to defend the form of advocacy we critique and to point us to errors in our description or argument. Niblett's article, however, fails to provide an accurate account of our position and thus fails to demonstrate to us where we might have erred.

\section{References}

Burns, D. P. \& Norris, S. P. (2009). Open-minded environmental education in the science classroom. Paideusis, 18(1), $35-42$.

Niblett, B. (2012). Integrating advocacy and environmental education: A response to Burns \& Norris. Padeusis, 20(1), 4-13.

\section{About the Authors}

David P. Burns is a faculty member in the Department of Educational Studies, Kwantlen Polytechnic University. Stephen P. Norris is Professor and Canada Research Chair in the Department of Educational Policy Studies, University of Alberta. David can be reached at david.burns@kwantlen.ca and Stephen can be reached at stephenn@ualberta.ca. 